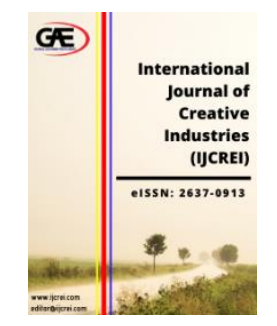

\author{
INTERNATIONAL JOURNAL OF \\ CREATIVE INDUSTRIES \\ (IJCREI) \\ www.ijcrei.com
}

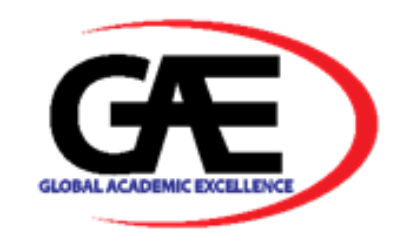

\title{
MALAY GAMELAN: PLAYING TECHNIQUES OF THE KEROMONG AND GAMBANG
}

\author{
Teuku Umar Ilany Teuku Iskandar ${ }^{1}$, Marzelan Salleh ${ }^{2 *}$ \\ 1 Faculty of Creative Arts, University Malaya (UM), Malaysia \\ Email: teukutote@icloud.com \\ 2 Faculty of Creative Arts, University Malaya (UM), Malaysia \\ Email: marzelan@um.edu.my \\ * Corresponding Author
}

\section{Article Info:}

\section{Article history:}

Received date: 17.10 .2021

Revised date: 30.10 .2021

Accepted date: 05.11.2021

Published date: 05.12.2021

\section{To cite this document:}

Teuku Iskandar, T. U. I., \& Salleh, M. (2021). Malay Gamelan: Playing Techniques of the Keromong and Gambang. International Journal of Creative Industries, 3 (8), 01-12.

DOI: $10.35631 /$ IJCREI.38001.

This work is licensed under CC BY 4.0 (c) 1

\begin{abstract}
:
Malay gamelan is a traditional music ensemble that accompanies the Joget Gamelan dance and was found in the palace of Johor-Riau, Pahang, and Terengganu in the 19th century, before disappearing in 1942. Malay Gamelan was exclusively taught in the palace orally, that is, through the process of listening, observing, memorising, and repeating; much like other classical Malay traditional arts. This study was initiated to discuss some aspects of Malay gamelan music in detail as there is little documentation regarding Malay gamelan in the academic world. Several writings on Joget Gamelan were produced based on the 1966 discovery in Terengganu and the inaugural performance in 1969 at the University of Malaya. However, attention to the different aspects of Malay gamelan music was not exhaustive. This study explores the playing techniques of keromong and gambang that were traditionally taught and passed down among Malay gamelan practitioners. A qualitative method was used in this research, whereby the earliest recordings of Malay gamelan music were analysed and interviews were conducted with informants, or also known as adiguru of Malay gamelan practitioners who studied directly with the last generation of Terengganu court musicians. The objective of this study is to 1) identify the techniques of keromong playing in Malay gamelan, and 2) identify the techniques of gambang playing in Malay gamelan. Findings from this study will provide an understanding of the musical instruments and what defines the style of Malay gamelan music, as well as become a guide for future researchers and practitioners in efforts to conserve and preserve the Malay traditional art.
\end{abstract}


Keywords:

Malay Gamelan, Playing Technique, Musical Aspect, Traditional Music, Palace Music

\section{Introduction}

Malay Gamelan is a traditional musical ensemble associated with the traditional Joget Gamelan. The discovery of a gamelan set at Istana Kolam in 1966 and Tengku Ampuan Mariam's revelation of the existence of a tradition of dance and music in the palace (Sheppard, 1967) sparked the interest of the researcher to conduct a study on Joget Gamelan. The discovery of this court tradition became important at that time because Joget Gamelan refers to a type of dance or dramatari performance accompanied by Malay gamelan. There was an awareness of the tradition of gamelan originating from Java as well as other types of gamelan in Indonesia such as Balinese gamelan and Sundanese gamelan, but it was not known to be in existence in Malaysia. The gamelan tradition in Malaysia known at that time was that of Javanese gamelan in Johor, played by the Johor people of Javanese descendant, accompanying a shadow puppet performance similar to the Javanese Wayang Purwa (Mat Piah, 1983).

The only formal record of a dance and gamelan music performance that took place at the Pahang palace was written in 1895 in The Malay Sketches, detailing the dance performances by budak joget, the beauty of the costumes, and spirited performance of gamelan, which went on from 10 p.m. until 5 a.m. (Swettenham, 1895). Frank Swettenham had received an invitation from the Sultan of Pahang to witness the exclusive dance and gamelan music performance known as Joget Pahang at the Pahang palace (Ahmad Farid Abd Jalal, 2008).

This study focuses on the exploration and investigation of playing techniques of the keromong and gambang. Previous studies have discussed in detail the instrumentation, organology, texture, and system of colotomic, and the essence and the uniqueness of the Malay gamelan. However, discussions based on instruments such as the keromong and gambang have yet to be published.

\section{Literature Review}

The researcher has outlined three topics in the literature review, namely the origin of the Malay gamelan tradition, the Malay gamelan instruments and the role of musical instruments in Malay gamelan. These topics were selected to examine the role of specific musical instruments, namely keromong and gambang, from various musical angles. Understanding the history, workings and role of the musical instruments is important in examining the development of variations of gamelan tradition in the archipelago.

\section{Origins of the Malay Gamelan Tradition}

Malay gamelan is a traditional music ensemble that accompanies a court dance rooted in the tradition of the Johor-Riau palace. The Bendahara Seri Maharaja Tun Ali, the Bendahara of Pahang (1806-1857) had travelled to Lingga to attend a royal festival graced with art performances including gamelan performances. The Bendahara subsequently brought home a 
set of seven musical instruments to Pekan, Pahang, along with musicians from Pulau Penyengat as instructors and formed the first group in Pahang (Ahmad Farid Abd Jalal, 2008; Ahmad Omar Ibrahim, 2005). The group is said to have performed during the celebrations for the royal wedding ceremony between Tengku Hussain, the eldest son of Sultan Abdul Rahman from Riau and Wan Esah, the younger brother of Bendahara Tun Ali, in 1811 (Sheppard, 1967).

The dance and music performances that originated from Riau-Lingga and were later named Joget Pahang began gaining a place in the Pahang palace and flourished during Sultan Ahmad's reign (1863-1914). There were three groups for the Joget Pahang, consisting of musicians and dancers managed by the queen and the sultan's wives (Sheppard, 1967, p.g. 150). The performances were only carried out in the palace, of which was witnessed by the first British Resident, Frank Swettenham in 1875. He wrote a book entitled Malay Nautch in 1878 and detailed the performances, dances, conductors and musical performances, which are the earliest written references to the performance of Joget Pahang at Istana Rupa.

The Sultan of Pahang, Sultan Ahmad, learnt the tradition from his mother, Che Zubedah. His daughter, Tengku Ampuan Mariam, then continued the Joget Pahang legacy and brought the tradition to Terengganu when she married Tengku Sulaiman, the second son of Sultan Zainal Abidin III (1881-1918) in 1913. After Sultan Sulaiman ascended to the throne, he and Tengku Ampuan Mariam played important roles in expanding the art of Joget Pahang by creating new dances and music, producing 95 compositions with 60 of them accompanying dances (Harun Mat Piah \& Siti Zainon Ismail, 1986). They both visited Indonesia to witness traditional performances, such as in Jakarta, Bogor, Medan, Sukabumi, and several other locations including Bangkok to delve into palace performances between 1928 and 1930 (Ahmad Omar Ibrahim, 2005). Love for the traditional arts was reflected in the manuscripts on dances by Tengku Ampuan Mariam while Sultan Sulaiman wrote songs and later changed the name Joget Pahang to Joget Gamelan Terengganu (Harun Mat Piah \& Siti Zainon Ismail, 1986).

However, the peak of Joget Gamelan Terengganu was short-lived as this tradition faced its downfall during the Second World War in 1941. The death of Sultan Sulaiman in 1942 impacted the development of Terengganu's Joget Gamelan tradition. Later discontinued, musical instruments were kept at Istana Kolam, Kuala Terengganu and Tengku Ampuan Mariam held a special ceremony with the dancers and musicians where they were required to swear before her to not discuss nor show any form of the repertoires to outsiders without her permission (Ahmad Omar Ibrahim, 2005). The traditions of this palace have remained buried for 24 years since 1942 .

\section{Malay Gamelan Instruments}

Malay Gamelan refers to a traditional ensemble consisting of bronze instruments of various forms. It plays an important role in accompanying the dances that flourished in the Malay sultanate palace on the peninsula in the 18th century. According to Mubin Sheppard (1967), the ensemble comprises seven musical instruments, i.e. a gambang, a pair of sarons, a keromong, a kenong, a pair of gongs and a gendang. Ahmad Omar Ibrahim (2005) suggested that the musical instruments are keromong, saron besar, saron kecil, gambang, gong besar, gong kecil, kenong and gendang according to the Malay gamelan musicians. However, Ahmad Omar Ibrahim (2005, p. 163) stated that Malay gamelan instruments comprised more than Copyright $\odot$ GLOBAL ACADEMIC EXCELLENCE (M) SDN BHD - All rights reserved 
seven instruments, and that Malay gamelan had many musical instruments in the early 19th century, but there was no evidence to support this claim. However, the opinion on the existence of additional instruments was further strengthened by the description of the gedemong, a musical instrument consisting of ten sets of small gongs similar to the keromong (Sheppard, 2011).

Although there are not many Malay gamelan instruments compared to the Javanese gamelan, the aspects of Malay gamelan music meet the gamelan music concept, as expressed by Perlman (2004):

Roughly speaking, we can divide these into three categories: the form-defining ("punctuating") instruments; instruments that bear the melodic skeleton or framework; and the "elaborating" parts. No matter how few instruments are available, each of the three categories must be represented: at least one punctuating instrument, one melodic-framework instrument, and a few elaborating parts. (p. 37)

According to Matusky \& Sooi Beng (2012), the Malay gamelan laras (tuning system) is likely to have been derived from the five-tone system (laras slendro) found in Javanese gamelan, where the Malay five-tone system has been modified and adapts the cypher notation based on the Indonesian kepatihan system. This opinion was also mentioned by Mohd Ghouse Nasaruddin (1983), who explained that the tone for the pentatonic scale in the Malay Peninsula is different from the Javanese slendro tone, based on evidence of the oldest Malay gamelan set in Pahang.

\section{Role of Instruments in Malay Gamelan}

The instruments can be divided into three musical aspects namely melody (keromong, gambang, saron besar and saron kecil), structure (kenong and gong) and time (gendang). Suggestions for the division according to the role of the instruments by the researcher are supported by Sumarsam (2002) who categorised three musical roles in Javanese gamelan as follows:

1. The instruments and vocalist that carry the melody in both elaborate and simpler forms. This group can be divided into three groups:

a. The instruments and vocalists that represent elaborate melodies. Employing a wide melodic range, the rebab, gendèr barung, gambang, sindhèn, and gérong have the important function of determining the melodic essence of compositions.

b. The instruments which play a melodic abstraction of a gendhing (balungan) within their one-octave range.

c. The instruments that melodically mediate between the group (a) and (b).

2. The instruments that regulate musical time: to set up the appropriate timing for a composition, control transition, and signal the end of the piece.

3. The instruments that underline the musical structure.

There are several types of classifications in the gamelan tradition such as classification by shape and size (Sutton, 1975), classification by organology of musical instruments (Kunst, 1987; Md Amin, Mohd Yusoff, \& Kechot, 2017) and classification according to the concept of Copyright $\odot$ GLOBAL ACADEMIC EXCELLENCE (M) SDN BHD - All rights reserved 
rhythm and song as stated by Warsadinigrat (Becker \& Feinstein, 1984). Sumarsam's view of the classification of musical instruments in gamelan based on the role of the instruments was chosen by the researcher as it is in line with the research topic and compatible with instrumentation on large and small scales, such as Malay gamelan.

\section{Methodology}

This study examines the playing techniques of keromong and gambang in Malay gamelan. A qualitative method was used in two phases, i.e., secondary and primary resources. In the early stage, a study of available academic documents was conducted. Scientific reference materials such as historical aspects, musical aspects and Malay gamelan traditions were collected from various sources such as archives, libraries, and agencies related to traditional arts.

The second phase involves the compilation of primary sources whereby audio and video recordings of the earliest Malay gamelan music performed by the last generation of Terengganu palace musicians were collected for analysis. The data were collected and transcribed into the form of music notation for analysis. Interviews with three Malay gamelan adiguru (master) were also conducted using a semi-structured interview format approach, with the questions related to the musical aspects and playing techniques of Malay gamelan.

\section{Findings and Discussion}

Based on the findings from the research, the researcher found that playing techniques in Malay gamelan for both keromong and gambang can be divided into two sections, which are the concepts of temu tiga and teknik asas of keromong and gambang.

Based on the audio recordings of the Malay gamelan performance by the last generation of palace musicians and interviews conducted with the three Malay gamelan adigurus, keromong and gambang techniques and patterns were identified and classified. Five songs were selected to be used in this study, namely Timang Burung, Topeng, Perang Manggung, Lambang Sari and Geliong. These selections were made based on the level of complexity of the playing techniques.

\section{Concept of Temu Tiga: Keromong's Mapping of The Hand Movements}

For the keromong, the researcher identified patterns used in playing certain melodic phrases based on hand movements. These hand movements can be classified into two approaches:

1. The hand movements for an ascending melody (note 1 to note 6 ).

2. The hand movements for a descending melody (note 6 to note 1 ).

When a melodic phrase moves to 3 , ascending from any low note ( 1 or 2$)$, the right and left hands will move from the low note, meeting in the middle of the keromong at note 3 , with the right hand on the upper 3 and the left hand on the lower 3, as shown below. 
Volume 3 Issue 8 (December 2021) PP. 01-12 DOI: 10.35631/IJCREI.38001

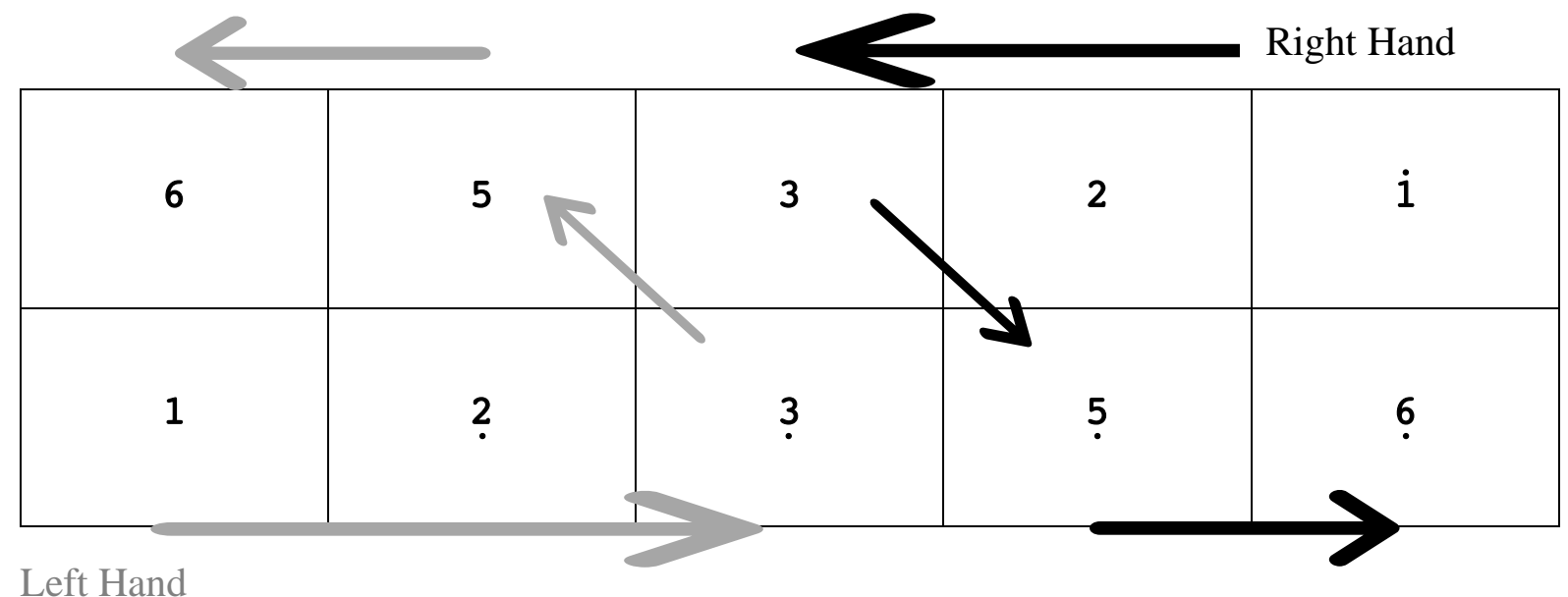

Figure 1. Hand Movements When Ascending from Note 1 to 6.

Next, when moving from note 3 towards note 6 , the movement of the hands will change, i.e. the right hand switches to the lower 5, and the left hand will shift to the upper 5, thus preventing the hands from intersecting when heading towards note 6. This same principle of hand movement is also used for melodies descending from note 6 to note 1 . When a melodic phrase moves to note 3 , descending from any high note ( 5 or 6$)$, the right and left hands will move from the high note, meeting in the middle of the keromong at note 3 , with the left hand on the upper 3 and the right hand on the lower 3 (Figure 2).

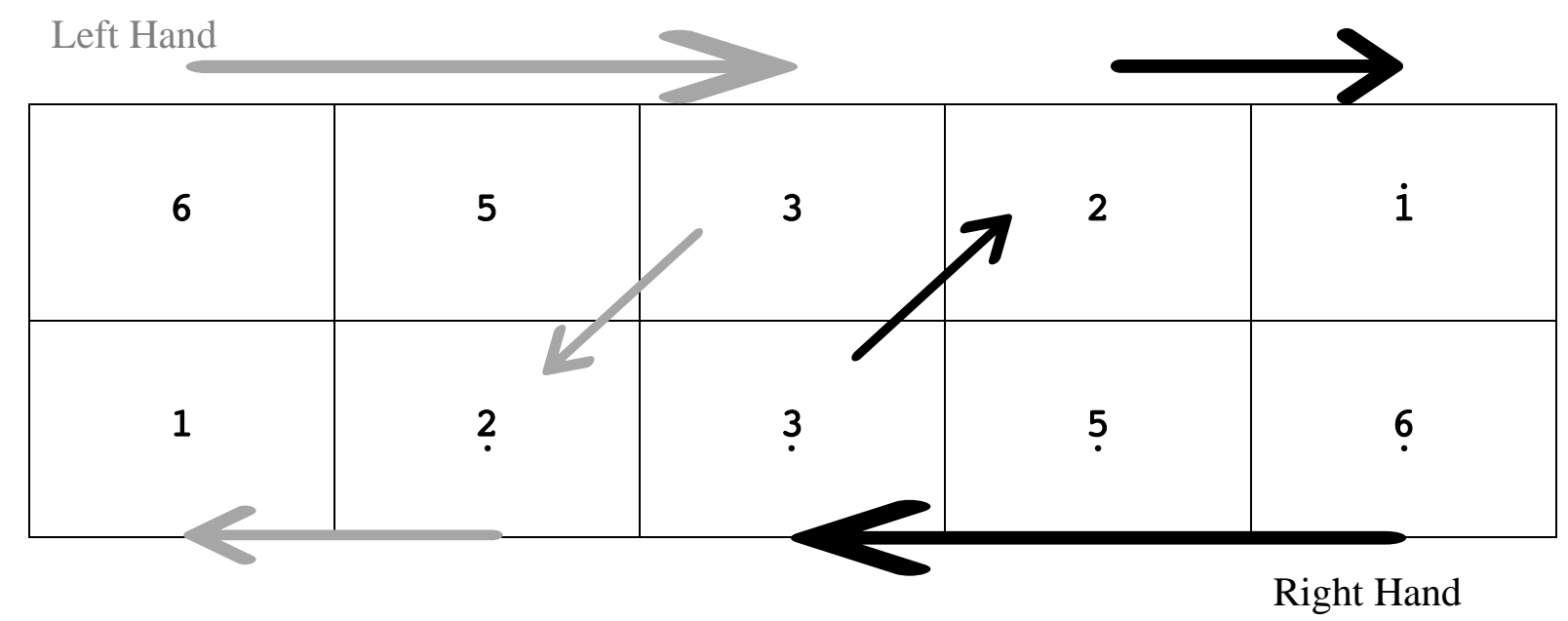

Figure 2. Hand Movement Descending from Note 6 to 1.

Based on this finding, it can be concluded that notes 1,2, 5 and 6 on the right area are played by the right hand while the left hand will play notes $1,2,5$ and 6 in the left area, with note 3 being played interchangeably according to the direction of the previous note.

In other words, for any note in the melody that will move to note 3 , it is necessary to go to note 3 with hand movements in parallel from the previous note, before moving to other notes. These hand movements centred on note 3 or based on the suggested temu tiga concept, became the Copyright $\odot$ GLOBAL ACADEMIC EXCELLENCE (M) SDN BHD - All rights reserved 
basis for a playing technique that produces unique features on the melody played by the keromong.

\section{Teknik Asas of Keromong and Gambang}

To identify the playing techniques, the researcher analysed hand movements and melodies by musicians who play bunga (embellishment). The researcher also made comparisons between lagu (melody) played by both sarons and bunga played by the keromong and gambang. This approach was taken because the researcher suggests that lagu by sarons are a reference or basis to the 'flowering' approach that is played by the keromong and gambang. The identified techniques are also in line with the temu tiga concept, as a framework to the basis of the keromong and gambang playing, classified as teknik asas (basic technique).

\section{Serentak}

When the keromong and gambang play the melody, at each end of the phrase, the keromong and gambang will play the note simultaneously in an octave. This technique can be found at the end of the phrase in any traditional Malay gamelan music. This technique is named serentak, the meaning of which describes the way the note beats are played. It can also be found in the Javanese gamelan, typically for the bonang, which is called the gembyang technique and performed in repetitive and patterned rhythms.

\begin{tabular}{|c|c|c|}
\hline Melodic Phrase & Serentak Technique & Western Notation \\
\hline $\begin{array}{llll} & 5 & 6 & i\end{array}$ & $\overline{33} \overline{55} \quad \overline{66} \underline{i}$ & $b^{b^{b}} 4^{c} \cdot \cdots 0^{\bullet}$ \\
\hline
\end{tabular}

Table 1. Serentak Technique.

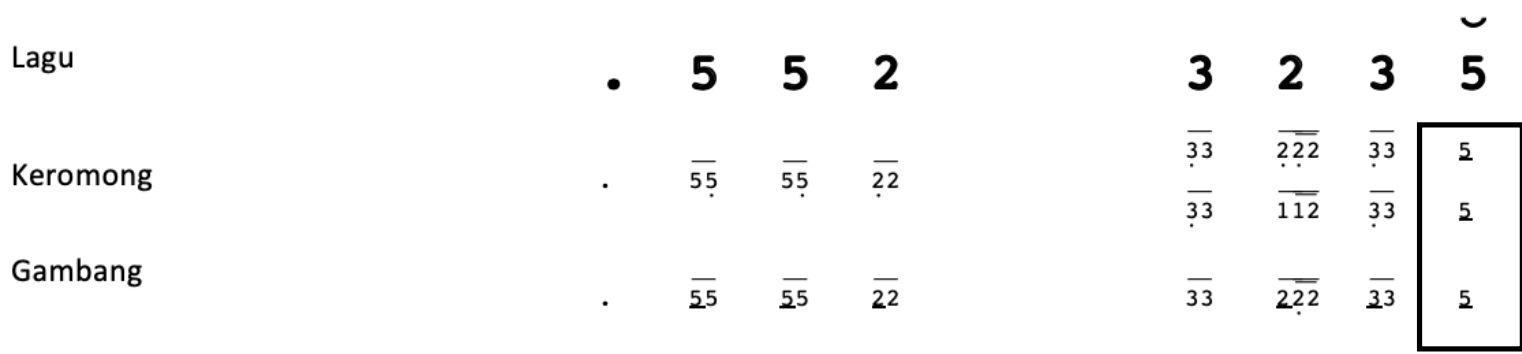

Figure 3. Timang Burung - Serentak Technique.

This serentak technique occurs at all ends of the phrase in the song Timang Burung, which is marked with the notes played by the kenong. The exception is in one phrase in which the keromong and gambang proceed playing to the next phrase, executing the bunga of the song. The serentak technique is also seen in certain places that are not at the end of a phrase but as an emphasis on a short melody or note. This serentak technique is not only applied in Timang Burung but also played by the keromong and gambang at the end of the melody phrase in all Malay gamelan songs. 
Gilir

The researcher has found that this technique is the most commonly found in the keromong playing where it refers to the stroke of a hand that plays the keromong melody in turns preceded by the left hand. Each saron note coincides with two quavers preceded by the left hand and then the right hand. The keromong will play the gilir technique on all melodic phrases and end with a serentak technique on the note at the end of the phrase.

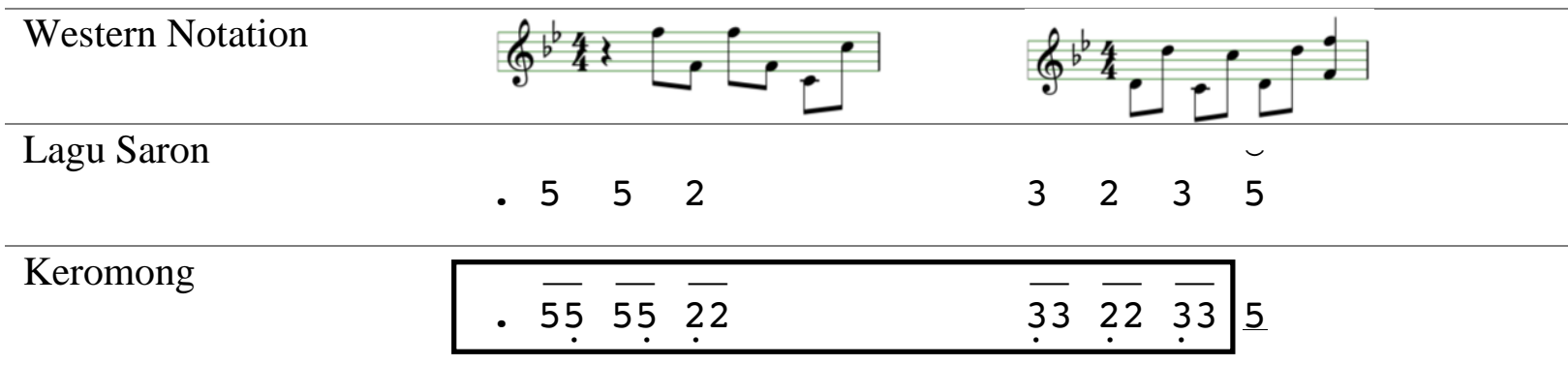

Table 2. Gilir Technique by Keromong.

The researcher argues that this technique is implemented by starting with the left hand first, then the right hand, just as how it was taught by informants and similar to the way the keromong is played in audio recordings. The findings also showed similar patterns of techniques in all gamelan songs. The gilir technique is played as the basis for the melody on the keromong, which is also the basis for bunga.

\begin{tabular}{|c|c|c|c|c|c|c|c|c|}
\hline Lagu & - & 6 & 6 & - & 6 & 6 & 3 & 5 \\
\hline \multirow{2}{*}{ Keromong } & \multirow{2}{*}{$\overline{.6}$} & \multirow{2}{*}{6} & \multirow{2}{*}{$\frac{66}{6}$} & \multirow{2}{*}{$\overline{.6}$} & $\overline{66}$ & $\overline{6 \overline{66}}$ & $\overline{3 ?}$ & $\overline{5 !}$ \\
\hline & & & & & $\overline{6 . \overline{2}}$ & $\overline{12}$ & $\overline{33}$ & $\overline{5}$ \\
\hline Gambang &.$\overline{6}$ & 6 & $\overline{66}$ &.$\overline{6}$ & $\overline{66}$ & $\overline{6 \overline{66}}$ & $\overline{33}$ & 55 \\
\hline Cincang & 6 & 1 & 1 & 3 & 3 & 1 & 1 & 2 \\
\hline Lagu & $\mathbf{i}$ & 6 & 5 & 3 & 2 & 2 & 1 & 2 \\
\hline Keromong & $\overline{1 i}$ & $\overline{66}$ & $\overline{5 !}$ & $\overline{32}$ & 2 & $\overline{222}$ & $\overline{13}$ & 2 \\
\hline Gambang & $\mathrm{ii}$ & $\overline{66}$ & $\overline{55}$ & $\overline{32}$ & $\overline{22}$ & $\overline{2 \overline{22}}$ & $\overline{13}$ & 2 \\
\hline
\end{tabular}

Figure 4. Perang Manggung - Gilir Technique.

\section{Ganda}

Ganda is a technique named as such to refer to doubling the stroke. This technique is commonly played by saron pekin and gambang. There are two types of doubling technique variations that 
the researcher has identified in the gambang playing technique, namely a) doubling the note on both hands, and b) doubling the note on the right hand, with a single stroke on the left hand.

The main characteristic of gambang playing is to play continuously, where the gambang plays the melody even if there is a break on certain phrases. The musician may play it softly at some parts but playing does not stop. With the continuously played melodic feature, the gambang melody fills in any gaps, creating a connection between lagu by the sarons and keromong.

\begin{tabular}{ccc}
\hline Melodic Phrase & Instrument & Ganda Technique \\
\hline 2356 & a) $\overline{22} \overline{3} \overline{3} \overline{5} \overline{5}$
\end{tabular}

Table 3. Ganda Technique by Gambang.

\begin{tabular}{|c|c|c|c|c|c|c|c|c|}
\hline Cincang & 2 & 1 & 1 & 3 & 5 & 1 & 1 & $\mathbf{i}$ \\
\hline Lagu & {$[:$. } & 1 & 12 & 3 & 5 & 3 & 2 & 1 \\
\hline Keromong & $\overline{.6}$ & $\overline{116}$ & $\overline{12}$ & $\overline{33}$ & $\overline{35}$ & $\overline{5 \overline{3}}$ & $\overline{52}$ & 1 \\
\hline Gambang &.$\overline{6}$ & $\overline{1 . \overline{6}}$ & $\overline{12}$ & $\overline{33}$ & $\overline{35}$ & $\overline{53}$ & $\overline{32}$ & 1 \\
\hline Cincang & i & 1 & 1 & 3 & 5 & 1 & 1 & 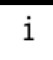 \\
\hline Lagu & • & 1 & 12 & 3 & 5 & 3 & 2 & $\overline{1}$ \\
\hline Keromong & $\overline{32}$ & $\overline{1 \overline{16}}$ & $\overline{12}$ & 33 & $\overline{35}$ & $\overline{5 \overline{53}}$ & $\overline{52}$ & $\overline{16}$ \\
\hline Gambang & $\overline{32}$ & $\overline{1 . \overline{6}}$ & $\overline{12}$ & 33 & $\overline{35}$ & $\overline{53}$ & $\overline{32}$ & 16 \\
\hline
\end{tabular}

Figure 5. Lambang Sari - Ganda Technique.

\section{Tingkah}

A rhythmic technique that stands out in keromong and gambang playing is the tingkah technique. Tingkah is performed by playing a certain rhythm on the note located on the second beat (the first strong beat in a bar) and occurs on even bars (the second, fourth and subsequent bars). Tingkah involves a rhythmic pattern played with both hands. 


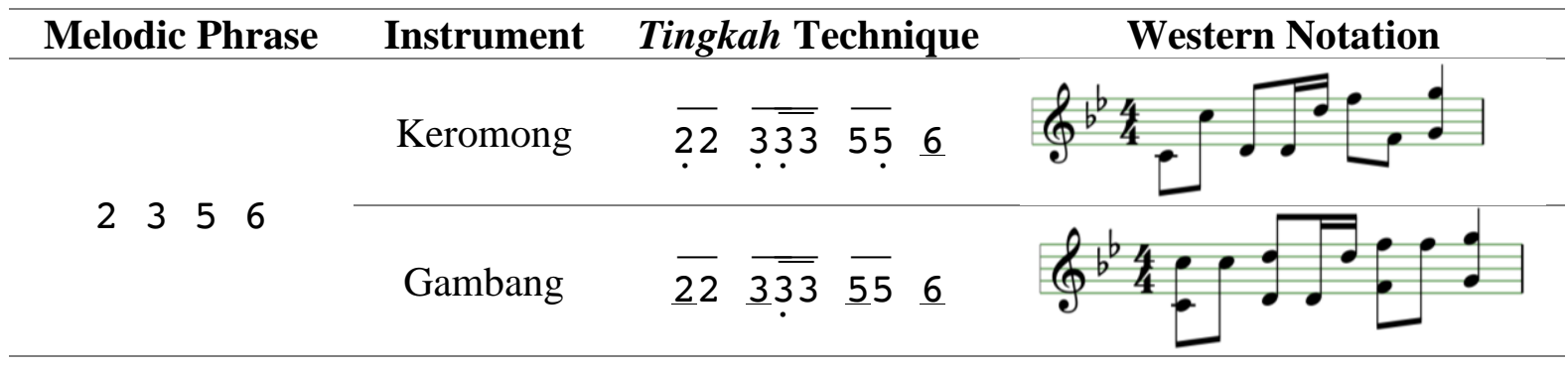

Table 4. Tingkah Technique by Keromong and Gambang

For keromong, the tingkah technique is performed by playing a single note, for example, note 2 will be played in a rhythmic pattern $\overline{222}$. The first two notes are played with the left hand, while the final note is played with the right hand, similar to the gilir technique, but with a new rhythm pattern. For the gambang, there is a slight difference in the approach of the stroke, but with the same rhythm. The tingkah technique is demonstrated by playing a single note, 3 for example, and it is played in a rhythmic pattern $\overline{\underline{3} \overline{3}}$. The first note is played with the serentak technique, while the two final notes are played separately with the gilir technique. For the gambang, the final two notes can be started with either hand.

\begin{tabular}{|c|c|c|c|c|c|c|c|c|}
\hline Lagu & • & 2 & 2 & • & 2 & 6 & 5 & 3 \\
\hline Keromong &.$\overline{2}$ & 2 & $\overline{22}$ &.$\overline{2}$ & $\overline{22}$ & $\overline{6 \overline{6 \sigma}}$ & $\overline{55}$ & $\overline{33}$ \\
\hline Gambang &.$\overline{2}$ & 2 & $\overline{22}$ &.$\overline{2}$ & $\overline{22}$ & $\overline{\underline{6 \sigma 6}}$ & $\overline{55}$ & $\overline{33}$ \\
\hline Lagu & • & 1 & 1 & • & 1 & 1 & 2 & च \\
\hline Keromong & $\overline{.6}$ & $\overline{1 \overline{16}}$ & $\overline{11}$ & $\overline{16}$ & $\overline{16}$ & $\overline{115}$ & 26 & 1 \\
\hline Gambang &.$\overline{6}$ & $\overline{1 . \overline{6}}$ & 11 & $\overline{16}$ & 16 & $\overline{53}$ & 56 & 1 \\
\hline
\end{tabular}

Figure 6. Lambang Sari - Tingkah Technique

This tingkah figure is the same for every phrase in a Malay gamelan song and occurs in even bars and the second beat. This tingkah is a technique that gives meaning to the term bunga, producing complex and interesting variations of the rhythmic melody. 


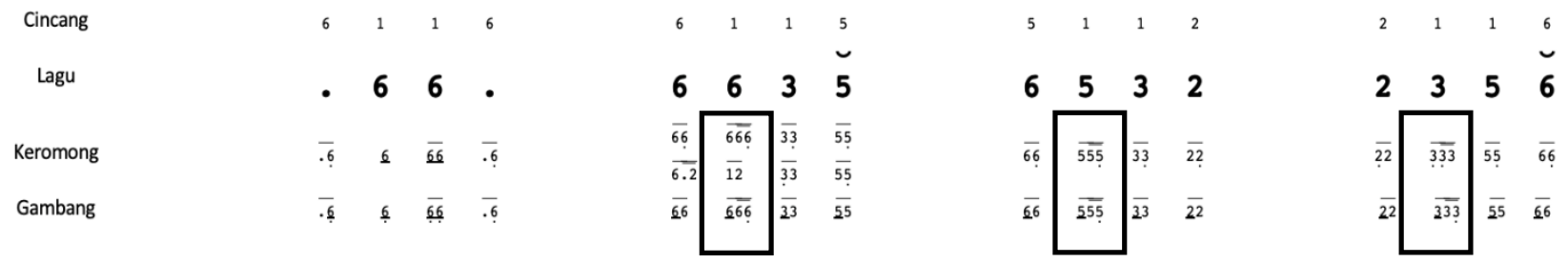

Figure 7. Perang Manggung - Tingkah Technique

The tingkah technique can be found in some other beats, where it can occur on each bar on the second beat, depending on the taste and feel of the musician at the time, i.e, rasa. This variation emerges because Malay gamelan songs are repetitive and the approach of playing the melody on keromong and gambang will not be the same each time when a gamelan song is repeated.

\section{Conclusion}

Based on the findings and discussions in this research, the researcher concludes that the keromong and gambang play an important role in defining the style of Malay gamelan playing techniques. It can be seen that the Malay gamelan tradition tends towards the approach of elaborating the melody compared to the gamelan tradition in Nusantara such as Javanese gamelan, which has a wider and more complex concept of melody and structure. Due to the limitations of instrumentation in the Malay gamelan, the keromong and gambang evolved as a musical instrument that plays variations of bunga that are based on the concept of temu tiga and teknik asas, supported by lagu of saron besar and saron kecil. Understanding the roles and techniques used by the keromong and gambang is fundamental to understanding the concept of bunga in Malay gamelan.

The researcher argues that an in-depth discussion of the musical aspects of traditional art, in particular Malay gamelan, will help increase its aesthetic values, growing from new roots through royal patrons and later bloom into local cultural contexts. The researcher believes that the result will not only open the door for discussion on Malay gamelan studies but also provide a guide to the efforts of driving continuity of Joget Gamelan towards, for it to carry on growing, in both the academic and traditional sense.

\section{Acknowledgement}

This work was supported by a grant from Universiti Malaya Impact - Oriented Interdisciplinary Research Grant Programme (IIRG).

\section{References}

Ahmad Farid Abd Jalal. (2008). Joget Pahang Gamelan Melayu: The Classical Ensemble of The Pahang Royal Court. Pekan, Pahang: Muzium Pahang, Jabatan Seni Dan Budaya, Kementerian Perpaduan, Seni Budaya Dan Warisan Malaysia.

Ahmad Omar Ibrahim. (2005). Joget Gamelan Terengganu \& Pahang: Penerus Tradisi Seni Persembahan Istana Kesultanan Melayu Melaka (Z. Jazlan, Ed.). Kuala Lumpur: Kementerian Kebudayaan, Kesenian dan Warisan Malaysia. 
Becker, J., \& Feinstein, A. H. (1984). Karawitan: Source Readings in Javanese Gamelan and Vocal Music. In J. Becker \& A. H. Feinstein (Eds.), Michigan Papers on South and Southeast Asia (Vol. 2). Ann Arbor, Michigan, USA: University of Michigan Press. Retrieved from https://doi.org/10.3998/mpub.17577

Harun Mat Piah, \& Siti Zainon Ismail. (1986). Lambang Sari: Tari Gamelan Terengganu. Bangi, Selangor: Pejabat Setiausaha Kerajaan Negeri Terengganu, Institut Bahasa, Kesusasteraan dan Kebudayaan Melayu Universiti Kebangsaan Malaysia.

Kunst, J. (1987). Music in Java. In E. L. Heins (Ed.), Music in Java (Third). Dordrecht: Springer Netherlands. https://doi.org/10.1007/978-94-009-3469-6

Mat Piah, H. (1983). Gamelan Malaysia : kertas-kertas kerja Simposium Gamelan Malaysia I. Siri Kebudayaan Kebangsaan, 28, 309. Kuala Lumpur: Kementerian Kebudayaan, Belia dan Sukan, Malaysia.

Matusky, P., \& Sooi Beng, T. (2012). Muzik Malaysia: Tradisi Klasik, Rakyat dan Sinkretik. Kuala Lumpur: Penerbit Universiti Malaya.

Md Amin, R., Mohd Yusoff, M. Y., \& Kechot, A. S. (2017). Communication, Instrumentation, Performance Arts of Malay and Java Gamelan. Jurnal Melayu, 272-288.

Mohd Ghouse Nasaruddin. (1983). Muzik Gamelan Dalam Konteks Muzik Etnik Malaysia. Siri Kebudayaan Kebangsaan, 28, 44.

Perlman, M. (2004). Unplayed Melodies: Javanese Gamelan and the Genesis of Music Theory (First, Vol. 110). United States of America: University California Press, Ltd.

Sheppard, M. (1967). Joget Gamalan Trengganu. The Malaysian Branch of the Royal Asiatic Society, 40(1), 149-152. Retrieved from http://www.jstor.org/stable/41491912

Sheppard, M. (2011). Malay Arts and Crafts (Second). Kuala Lumpur: The Malaysian Branch of the Asiatic Society. Retrieved from mbras@tm.net.my

Sumarsam. (2002). Introduction to Javanese Gamelan. (1), 28. Retrieved from https://sumarsam.web.wesleyan.edu/Intro.gamelan.pdf

Sutton, R. A. (1975). The Javanese Gambang and Its Music. University of Hawai'i.

Swettenham, F. (1895). Malay Sketches (Third). London \& Edinburgh: Ballantyne Hanson \& Co. Retrieved from http://www.archive.org/details/malaysketchesOOswet 